\title{
Critical Literacy Model On Students In Preparing Final Assignments To Avoid Plagiarism
}

\author{
Kinanti Resmi Hayati ${ }^{1}$,Zawawi ${ }^{2}$, Endang Sholihatin ${ }^{2}$ \\ ${ }^{1}$ Department of Industrial Engineering, Faculty of Engineering, UPN "Veteran" Jawa Timur, Surabaya, Indonesia \\ 1Department of Management Economic, Faculty of Economic and Business, UPN "Veteran” Jawa Timur, Surabaya, Indonesia \\ *Corresponding Author: kinantihayati@gmail.com
}

How to Cite : Hayati, K., R., Sholihatin, E. (2020). Critical Literacy Model On Students In Preparing Final Assignments To Avoid Plagiarism. International Journal for Educational and Vocational Studies, 2 (1), 74-78. DOI: https://doi.org/10.29103/ijevs.v2i1.1998

\section{ARTICLE HISTORY}

Received: 13 October 2019

Revised: 22 December 2019

Accepted: 26 January 2020

\section{KEYWORDS}

Critical Literacy;

Final Assignment;

Plagiarism;

\begin{abstract}
The aim of this study is to develop a Critical Literacy model for Management Economics department's Students of economics and business faculty of UPN "Veteran" Jawa Timur in Arranging Final Project to Avoid Plagiarism. The research method uses a qualitative and quantitative approach which is applied research with case studies. The research's location is in Management Economics department's Students of economics and business faculty of UPN "Veteran" Jawa Timur. The data sources are students, lecturers and administrative staff in Management Economics department. Primary data are questionnaire results and data from interviews. Secondary data are from documents, observation data, and media. The implementation of data collection in the field is regulated through the following strategies, (a) the determination of informants by purposive sampling (for key informants) and snow ball for informant development, (b) interviewing informants, (c) taking notes, (d) asking descriptive and structural question, 5) conducting interview analysis, (e) making domain analysis, (f) finding themes according to the research problem, $(\mathrm{g})$ surveying to students. The research checks the data validity by using data source triangulation techniques. The research conclusions are formulated a critical literacy model that can be applied by economics management study program Management Economics department's students in preparing Final Project to avoid plagiarism; 1 ) students prepare topics; 2) students look for references that are relevant to the topic; 3) students start to compile scientific papers (Final assignment) with the correct paraphrasing, quotation, and citation/bibliography techniques; 4) check plagiarism; 5) Similarity tolerance with maximum of $30 \%$; and 6) Final assignment avoids plagiarism.
\end{abstract}

This is an open access article under the CC-BY-SA license.

\section{INTRODUCTION}

A quality education process based on competence, capacity, capability, and positive character in globalization era is very important. Global competition in work life is an inevitable dynamic since the opening of free markets. The dynamics above require higher education providers to have the best quality. Along with the high demand for education, especially in making the final assignment, not a few students use instant methods in compiling the final assignment by plagiarism and academic cheating which is a form of ethical violations in education. Academic cheating (academic fraud) has become a prominent phenomenon in recent years, the research concludes that up to $70 \%$ of students cheat at least once while studying at university, and $25 \%$ cheat more than once (Lozier, 2010). Even in Tempo magazine on February 2, 2013 it was also reported that at least 125 students of Harvard University, Cambridge, Massachusetts in August 2010 carried out a mass-context scandal. It's really worrying, one of the best universities in the world is tarnished its good name due to academic cheating that is starting to bloom among students or lecturers. In Indonesia, many academic fraud cases have been revealed, for example in 2010 the revocation of a professor's title as a lecturer was found copying the others works and plagiarism of undergraduate thesis by two different lecturers in their efforts to obtain credit for their appointment. Academic cheating is not a new thing in education world, especially students who cheating on exams, either looking at books, carrying small notes, looking for answers by browsing through mobile phones or copying the assignments of their friends' work to complete the final assignment. Unconsciously, students have committed acts that lead to academic cheating. 
Plagiarism is the deliberate use of other people's ideas and works without clear citation of the information source. Fish and Hura (2013) define plagiarism as the act of using the work of other writers without quotations, and claim it as their own work. According to Herqutanto (2013) the act of plagiarism is called plagiarism, which means taking the essays (opinions and so on) of others and claiming them as their essays, for example publishing other people's papers on behalf of themselves; tracing. The results of the study by Suwarjo et al. (2012) found a form of plagiarism in students who refer to and quote terms, words/sentences, data/info from a source without citing the source adequately. A total of 1405 frequencies $(63.29 \%)$, refer to randomly terms, words/ sentences, data/info from a source without mentioning the source in the quotation notes and without citing the source adequately. A total of 391 frequencies (17.6\%) use opinion ideas, views/theories without adequately mentioning the sources. A total of 393 frequencies (17.1\%) formulate in their own words and sentences from the source of words, sentences, opinions/theories without adequately mentioning the sources. Regulation of Law Number 20/ 2003 , it is written that the perpetrators of plagiarism are given sanctions that the graduates whose final assignment is used to obtain academic, professional or vocational degrees, are proven to be plagiarized, revoked their titles (article 25 paragraph 2). Then the graduates mentioned in Article 25 paragraph 2 are sentenced to a maximum imprisonment of two years, and/ or a maximum fine of Rp. 200,000,000 (two hundred million rupiah).

The importance of this research that students have critical literacy skills, especially for management economics department students in preparing the final assignment to avoid plagiarism. This is based on academic regulations and ethics that plagiarism is a crime in education. Plagiarism is not a reflection of the academic community. Self-awareness, personal attitude, self-competence, internet facilities, and academic control are the factors in forming students' perceptions of plagiarism. Based on the background of the problem above, the writer is interested in conducting a study entitled Critical Literacy Model in Management Economics Department Students of Economics and Business Faculty of UPN "Veteran" Jawa Timur in Arranging Final Assignment to Avoid Plagiarism. Based on the description, the research purpose is to arrange a Critical Literacy model for Management Economics department Students in Arranging Final Project to Avoid Plagiarism. The result of the study can upgrade the knowledge about critical literacy and reduce plagiarism among students.

\section{Plagiarism and Critical Literacy}

Alexander Lindsey in his book of "Plagiarism and Originality" as quoted in Soelistyo (2011: 8-9) explains, plagiarism is defined as the act of plagiarizing the ideas, ideas or works of others to be recognized as one's own work or to use other people's work without mentioning the source so that it raises false assumptions or wrong about the origin of an idea, idea or work. Because this definition does not specifically limit the creation of written works, plagiarism can also be used to express the plagiarism of ideas, ideas or architectural works.

The definition of plagiarism in the Minister of Education Regulation of the Indonesia Republic Number 17 of 2010 specifically in Chapter I Regarding General provisions of Article 1 is "intentional or unintentional act in obtaining or trying to obtain credit or the value of scientific work, by quoting part or all of the work and / or work other parties' scientific work which is recognized as their scientific work, without stating the source precisely and adequately. Plagiarism is not only about asking for permission, getting permission from the creator or merely mentioning the source. According to Julissar, as quoted by Soelistyo (2011: 34) concludes several definitions of plagiarism, or plagiarism based on the results of his research, those are: 1) The use of ideas or ideas of others listed in the paper without mentioning the identity of the original source; 2) Using or quoting other people's words, sentences and paragraphs in a paper without quotation marks and/or citing the original source; 3) Using the expressions, descriptions, and explanations of others in a scientific paper without quoting and / or citing the original source; 4) Using facts in the other's data and information form which is the result of his research as outlined in a paper without mentioning the identity of the original source; 5) Changing the identity of the writer/creator from another person's written work with their own identity so that the work seems to be his own work. However, plagiarism should not be considered as a virus which is always present in a person's work.

Plagiarism can be avoided or prevented, unfortunately plagiarism phenomenon is endemic today, making people lazy to work, especially writing. According to Soelistyo (2011: 35) things that are not classified as plagiarism or plagiarism are: 1) Using information in the form of general facts; 2) Rewrite (by changing sentences or paraphrases) other people's opinions by providing a clear source; 3) quote other's writing adequacy by giving a clear boundary to the quotation section and writing down the source. Critical literacy deals with critical thinking and critical awareness. The concept of critical literacy was adopted from the analysis of critical discourse put forward by Norman Fairclough. Critical discourse analysis provides theories and methods that can be used to conduct empirical studies of the relationship between discourse, social and cultural development in different social domains. The problem is many cases of plagiarism among students in preparing their final assignments. This research is applied research whose urgency is to provide a solution for UPN "Veteran" Jawa Timur students' plagiarism problem practically. Critical literacy is related to critical thinking and critical awareness. Text that is read critically should be able to teach students to think critically to develop scientific and honest character (not plagiarism) in preparing the final assignment (mini thesis, thesis and dissertation). Based on these problems, 
the Critical Literacy Model research on Management Economics department Students in Arranging Final assignment to Avoid Plagiarism needs to be done.

\subsection{Paraphrasing Techniques}

The meaning of paraphrases according to KBBI is the process or results of re-expressing a speech from one level or kind of language into another without changing its meaning. Paraphrases give the possibility to give a different emphasis from the original author

The paraphrase technique can be carried out as follows.

a) Read the text entirely to be paraphrased.

b) Understand the whole topic of the text.

c) Determine the main points of discourse.

d) Determine speech that wants to become a variation.

e) Arrange the points without changing meaning.

f) Perfecting the mind

g) In explanatory sentences, it is sufficient to take on the point, illustrations and the examples can be ignored.

h) Re-describe with your own language or words and the words should be commensurate, effective, concise, and easy to understand.

The characteristics of paraphrases are different forms of speech, the substance does not change, the meaning of speech is the same, and the language / way of delivery is different.

\section{METHODS}

This research uses qualitative and quantitative approaches which are applied research with case studies.
The location of this research is in Management economics department of economics and business faculty of UPN Veteran Jawa Timur. The data source of this research are students, lecturers, leaders and administrative staff'of Management economics department of economics and business faculty of UPN Veteran Jawa Timur. Primary data is questionnaire results and interview data form. Secondary data are documents, observation data, and media. The implementation of field data collection is regulated through the following strategies, (a) the determination of informants by purposive sampling (for key informants) and snowball for the development of informants, (b) interviewing informants, (c) taking notes, (d) asking descriptive and structural questions, 5) conducting interview analysis, (e) making domain analysis, (f) finding themes according to the research problem, (g) surveying students. (h) Checking the validity of the data using data source triangulation techniques.

\section{RESULTS AND DISCUSSION}

\subsection{Critical Literacy Model for Management Economics Department of Economics and Business faculty of UPN "Veteran" Jawa Timur in arranging Final assignment to avoid Plagiarism.}

The model in critical literacy is to write scientific papers, especially the final assignment to avoid plagiarism in the form of diagram. The diagram below is a critical literacy model that can be applied by Management economics department of economics and business faculty of UPN Veteran Jawa Timur in preparing the Final assignment to avoid plagiarism.

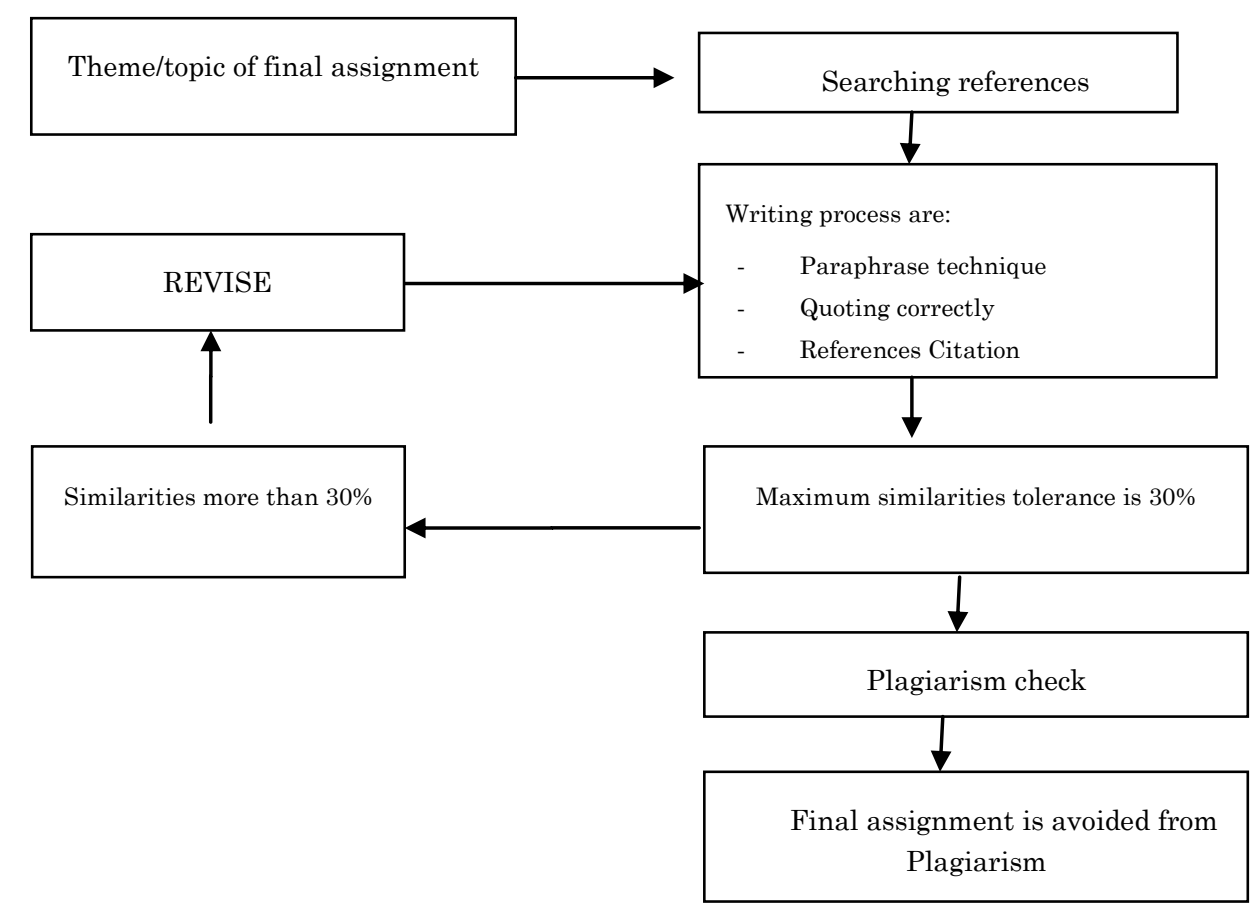

Figure 1. Models in Critical Literacy for arrranging final asssignment to Avoid Plagiarism 
Based on the diagram above, it implied that students are required to prepare a topic or theme in preparing scientific papers (Final assignment). Next, students are required to find references based on the topic or theme. This is quite important in writing a scientific work (Final assignment) because it takes a valid source as a basis or reference when writing an object issue which is happening. When students begin to write a scientific work (Final assignment), they are required to be able to apply paraphrase techniques in quoting a text, both from journals and books properly to avoid plagiarism. Students are also required to be able to make citations or bibliography correctly in accordance with the rules of writing scientific papers. After students finish writing the scientific work (Final assignment), it is necessary to check the plagiarism to ensure that there is no element of plagiarism in the scientific work writing. The maximum similarity tolerance is $30 \%$. If in plagiarism check the level of similarity or similarity is less than $30 \%$ so it can be concluded that the scientific paper (Final assignment) is succeeded in avoiding the element of plagiarism. However, if after checking plagiarism shows a level of similarity is more than $30 \%$ so the scientific work (Final assignment) must be revised. In the revision process, it is necessary to carry out the writing activities with the correct paraphrasing techniques as well as correct citations.

\section{CONCLUSION}

Based on the description above concluded that the critical literacy model can be applied by Management economics department of economics and business faculty of UPN Veteran Jawa Timur in preparing the Final assignment to avoid plagiarism, those are 1) students prepare topics, 2) students search for references accordance to the topic, 3) students begin to arrangescientific papers (Final assignment) with correct paraphrasing, quotation, and citation / bibliography techniques. 4) check plagiarism, 5) $30 \%$ maximum Similarity tolerance, and 6) Scientific Work (final assignment) avoid plagiarism.

Next, the advice that can be given after conducting this research is that students in general should have critical literacy skills, especially for Management economics department of economics and business faculty of UPN Veteran Jawa Timur in preparing their final assignment to avoid plagiarism. it based on academic regulations and ethics that plagiarism is a crime in education and plagiarism is not a reflection of academic community. Self-awareness, personal attitude, self-competence, internet facilities, and academic control are the factors which create students' perceptions of plagiarism. Furthermore, advanced researchers are advised to apply this model in other departments or faculties in order to increase critical literacy knowledge and reduce plagiarism among students.

\section{REFERENCES}

Abidin, Y. 2012. Pembelajaran Bahasa Berbasis Pendidikan Karakter. Bandung: Refika Aditama

Ajayi, L. 2012. Video "reading" and multimodality: A study of ESL/literacy pupils' interpretation of Cinderella from their socio-historical perspective. The Urban Review. 44(1): 60-89

Ajayi, L. 2015. Critical multimodal literacy: How Nigerian female students critique texts and reconstruct unequal social structures. Journal of Literacy Research. 47(2): 216-244

Alwasilah, AC. 2012. Pokoknya Rekayasa Literasi. Bandung: PT. Kiblat Buku Utama

Anstey, A. \& Bull, G. 2006. Teaching and Learning Multiliteracies: Changing Times, Changing Literacies. Newark, DE: International Reading Association

Brady, D.R. and Asselin, M.E. 2016. Exploring outcomes and evaluation in narrative pedagogy: An integrative review. Nurse education today. 45: 1-8

Beilke, J. 2005. Whose World This ?. Journal of Multicultral Education. Indiana : Ball State University. 5: 2-7

Burbules, N. C., \& Berk, R. 1999. Critical thinking and critical pedagogy: Relations, differences, and limits. Critical theories in education: Changing terrains of knowledge and politics. 45-65.

Cooper, K., \& White, R. E. 2008. Critical literacy for school improvement: an action research project. Improving Schools. 11(2): 101-113.

Corbin, J., \& Strauss, A. 2008. Basics of qualitative research: Techniques and procedures for Developing grounded theory. Los Angeles, CA: SAGE.

Dalman. 2014. Keterampilan Menulis. Jakarta: Raja Grafindo Persada

Fairclough, N. 1992. Critical language awareness. London: Longman

Freire, P.,\& Macedo,D. 2005. Literacy: Reading the Word and the World. London : Routledge Classics

Freire, P. 2008. Pendidikan Kaum Tertindas [Tim Redaksi LP3ES. Trans]. Jakarta : LP3ES

Giroux, H. A. 2007. Introduction: Democracy, education, and the politics of critical pedagogy. Counterpoints

Hammond, J. \& Macken-Horarik, M. 1999. Critical literacy: Challenges and questions for ESL classrooms.TESOL Quarterly. 33 (3): 528-543

Hendriani, A, Nuryani, P, Ibrahim T. 2017. Desain Pendidikan Hadap Masalah Berbasis Literasi Kritis di Sekolah Dasar. Laporan Penelitian Afirmasi LPPM UPI

Ibrahim, T. 2017. Dialog Landasan Pedagogik. Bandung: Rizki Press 
Ioannidou, E. 2015. Critical literacy in the first year of primary school: Some insights from Greek Cypriot classrooms. Journal of Early Childhood Literacy, 15(2): 177-202

Kesuma, D. \& Ibrahim, T. 2016. Struktur Fundamental Pedagogik (Membedah Pemikiran Paulo Freire). Bandung : Refika Aditama

Koh, A. 2002. Towards a critical pedagogy: creating "thinking schools" in Singapore. Journal of Curriculum Studies. 34(3): 255-264

Kucer, S. 2005. Dimensions of Literacy: A Conceptual Base for Teaching Reading and Writing in School Settings. Second Edition. London: Lawrence Erlbaum Associates, Publishers

McMillan, James H. \& Schumacher, Sally. 2001. Research In Education, A Conceptual Approach (Fifth ed.). New York: Addison Wesley Longman, Inc

Miles, B.B., dan A.M. Huberman, 1992. Analisa Data Kualitatif. Jakarta: UI Press

Moleong, Lexy J. 2006. Metodologi Penelitian Kualitatif. Bandung: PT. Remaja Rosda Karya.

Morrell, E. 2009. Critical research and the future of literacy education. Journal of Adolescent \& Adult Literacy. 53(2): 96-104.

Nasiroh, E. 2015. Penerapan Metode Pembelajaran Berbasis Skemata Kritis Untuk Meningkatkan Kemampuan Literasi Kritis. Bandung : Skripsi UPI

Pescatore, C. 2007. Current events as empowering literacy: For English and social studies teachers. Journal of Adolescent \& Adult Literacy, 51(4): 326-339

Priyatni. 2011. "Pengembangan Bahan Ajar Membaca Kritis Berbasis Intervensi Responsif dengan Multimedia”. Disertasi Program Studi Pendidikan Bahasa Indonesia, Program Pasca Sarjana: Universitas Negeri Malang. 